www.czasopisma.marszalek.com.pl/pl/10-15804/npw

\title{
MACIEJ ZUZIAK
}

Uniwersytet Śląski

ORCID ID: https://orcid.org/0000-0003-4297-4973

\section{Konflikt na Morzu Południowochińskim}

\section{Zarys historyczny, omówienie problemów natury politycznej i prawnej ze szczególnym uwzględnieniem elementów polityki zagranicznej Chin}

\section{The South China Sea dispute: historical overview, discussion of problems of a political and legal nature with particular emphasis on elements of China's foreign policy}

\section{Abstract}

The South China Sea is one of the key interests of Chinese foreign policy. The author of the provided article will analyse geopolitical factors, including estimation of the total value of the resources of the South China Sea, further providing the reader with information about international law regulations regarding the analysed matter, as well as presenting the current situation on the South China Sea. During the realisation of said plan, the author will try to prove the thesis that the South China Sea is of utmost importance to the Republic of China, the thesis that international law is unable to resolve disputes arising from said sea, as well as the thesis that Chinese presence is gradually increasing on the South China Sea. After proving all of the highlighted theses, the author will present the most probable political forecast, as well as opinions presented in literature regarding this matter.

Keywords: Asia, China, South China Sea, ASEAN, UNCLOS 


\section{Конфликт в Южно-Китайском море: исторический обзор, обзор пра- вовых и политических трудностей с уделением особого внимания элементам внешней политики Китая}

\section{Аннотация}

Южно-Китайское море - это одна из главных тем, связанных с внешеей политикой Китайской Народной Республики. Автор статьи сделает анализ геополитических взаимоотношений на Южно-Китайском море, в том числе определит общую ценность натуральных залежей этой акватории, а также юридическую ситуацию на море. Автор представит и постарается доказать тезис о том, что Южно-Китайское море - это одна из главных территорий в создании внешеей политики Китая. Кроме того, представит тезис, что юридическо-международные договоры не в состоянии разрешать конфликты на море. В статьи идёт речь также о увеличении присутствия Китайской Народной Республики в этом регионе. В конце концов автор представит возможные варианты развития ситуации и мнения учёных на эту тему.

Ключевые слова: Азия, Китай, Южно-Китайское море, Ассоциация государств Юго-Восточной Азии (ASEAN), Конвенция Организации Объединённых Наций (OOH) по морскому праву

\section{Słowem wstępu oraz teza pracy}

Morze Południowochińskie, chociaż często pomijane, szczególnie w relacjach europejskich mediów, jest jednym z największych wyzwań chińskiej polityki międzynarodowej oraz prawdopodobnie jednym z najbardziej niebezpiecznych ewentualnych punktów zapalnych, na którym incydenty międzynarodowe mogą doprowadzić nie tylko do potencjalnie niebezpiecznej potyczki, ale i do pełnowymiarowego konfliktu. Morze Południowochińskie jest również jednym z najważniejszych akwenów strategicznych i jednym z nielicznych, których sytuacja polityczna nie jest jeszcze w pełni klarowna. Chociaż truizmem jest powtórzenie hasła, w myśl którego uzyskanie kontroli nad Morzem Południowochińskim jest jednym z chińskich priorytetów, to z perspektywy europejskiej znacznie ważniejsze i mniej oczywiste są konsekwencje włączenia tego akwenu do wyłącznej strefy wpływów chińskich. Bowiem od spełnienia się tego scenariusza zależy nie tylko rozkład sił oraz sytuacja geopolityczna w Azji Wschodniej, ale również cała polityka zagraniczna Państwa Środka, w tym ewentualne decyzje 
dotyczące projektów, takich jak Nowy Jedwabny Szlak, których znaczenie dla Europy jest oczywiste. Nie będzie przesadą stwierdzenie, że od uzyskania dominacji na Morzu Południowo- i Wschodniochińskim zależeć będzie to czy Chińska Republika Ludowa stanie się supermocarstwem w rozumieniu Stanów Zjednoczonych czy dawnego Związku Radzieckiego, tj. państwem, które posiada wyłączną strefę wpływów w krajach ościennych oraz od decyzji politycznych którego zależy całokształt przyległego regionu. Porażka w podporządkowaniu sobie krajów nadbrzeżnych Morza Południowochińskiego oznaczać może, że chociaż Chiny posiadają gospodarkę zdolną do kształtowania ekonomii światowej, to jednak pozostaną państwem zamkniętym, niezdolnym do rzeczywistej kontroli sytuacji politycznej państw sąsiadujących.

\section{Uwarunkowania strategiczne oraz wartość zasobów Morza Południowochińskiego}

Morze Południowochińskie, które rozciąga się od Singapuru i bełtu Malezyjskiego na południowym zachodzie, aż do Tajwanu na północy, jest nie tylko miejscem przez które przechodzą jedne z najważniejszych szlaków handlowych na świecie, ale również jednym z nielicznych mórz, którego bogactwa naturalne nie są aktualnie eksploatowane (US EIA, 2013).

Powierzchnia morza obejmuje kilkaset małych wysp, skał i raf, w większości zgromadzonych w dwóch obszarach, to jest łańcuchy wysp zwanym Paracelskim i łańcuchu wysp Spratly. Już teraz należy zaznaczyć, że większość tych nadwodnych mas nie nadaje się do zamieszkania, stąd ilość terytorium zdatnego do zabudowy na Morzu Południowochińskim jest bardzo ograniczona. W przypadku wcześniej wspomnianych wysp Spratly są to zaledwie trzy mile sześcienne (US EIA, 2013).

Według szacunku U.S. Energy Information Administration (a obliczenia te w zasadzie pokrywają się z tymi opublikowanymi przez rząd ChRL) Morze Południowochińskie może zawierać około 190 trylionów stóp sześciennych gazu ziemnego, przy czym liczba ta ogranicza się tylko do złóż, z których wydobycie byłoby potencjalnie opłacalne. Dodatkowo, według wyników badań opublikowanych przez U.S. Geological Survey (USGS) Morze Południowochińskie może zawierać dodatkowe zasoby gazu ziem- 
nego, których eksploatacja nie jest jednak w oczywisty sposób opłacalna (70 lub 290 bilionów stóp sześciennych gazu ziemnego zależnie od przeprowadzonych obliczeń). Chociaż określenie dokładnej ilości gazu ziemnego na terytorium spornego morza jest w obecnych warunkach niemożliwe (w pracach badawczych przeszkadza przedmiotowy spór) to już teraz można stwierdzić, że Morze Południowochińskie jest siódmym co do wielkości złóż terenem o wciąż niezbadanym potencjale wydobywczym na świecie.

\section{Wykres 1. Wielkość nieodkrytych złóż gazu ziemnego na Morzu Południo-} wochińskim wraz z porównaniem (US EIA, 2013).

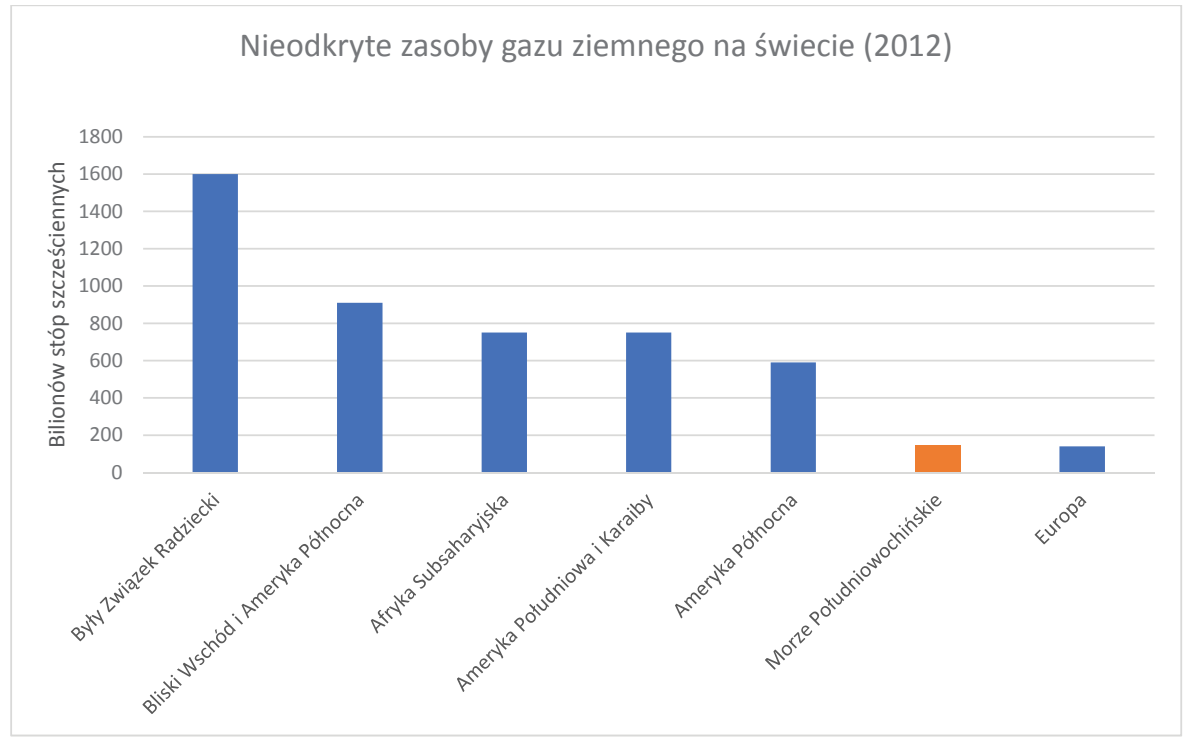

Podobne problemy szacunkowe pojawiają się przy wyliczaniu wielkości złóż ropy. Według szacunków U.S. EIA należy mieć na względzie około 11 miliardów baryłek ropy naftowej (znowu liczba ta pokrywa się z danymi opublikowanymi przez rząd ChRL, jak i pomijane są tutaj złoża, których potencjał ekonomiczny pozostaje nieznany). Czyni to Morze Południowochińskie siódmym najważniejszym co do wielkości złóż terenem, którego potencjalne złoża nie zostały jeszcze w pełni odkryte. 
Wykres 2. Wielkość nieodkrytych złóż ropy naftowej na Morzu Południowochińskim wraz z porównaniem (US EIA, 2013).

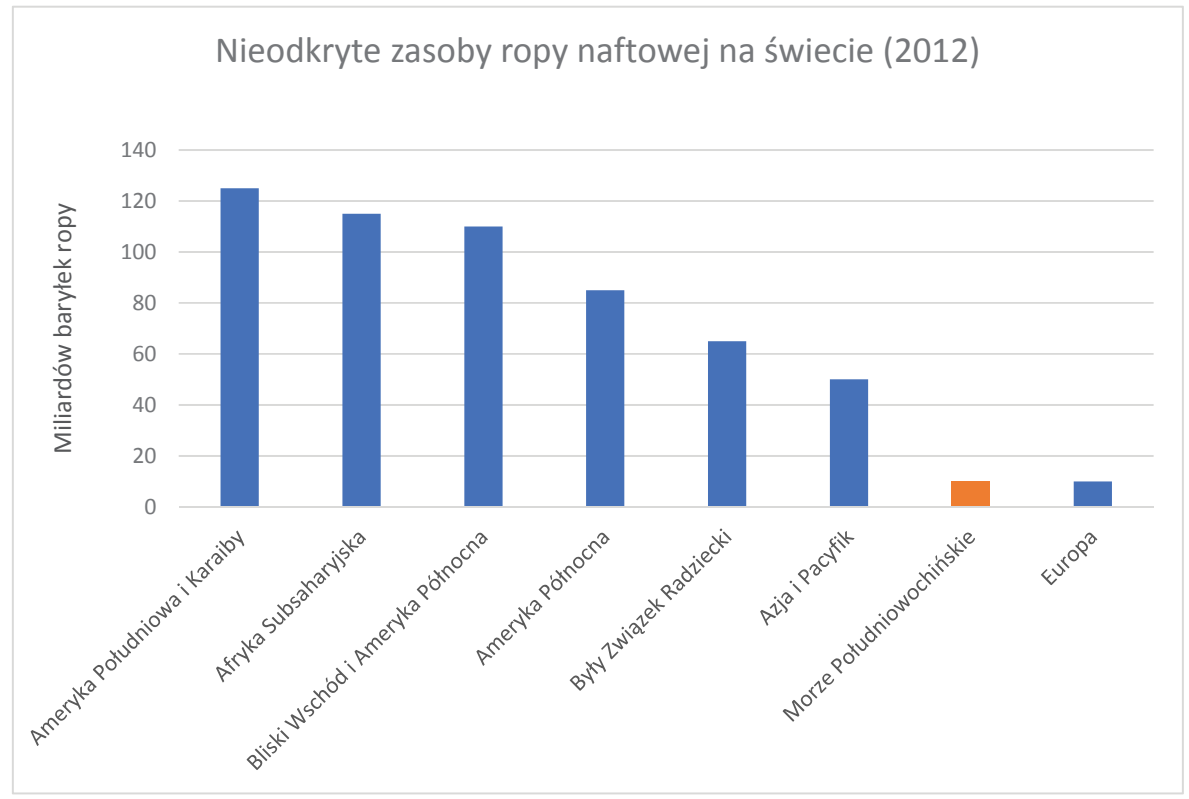

Konstytutywnym elementem znaczenia strategicznego Morza Południowochińskiego nie są jednak złoża ropy naftowej czy gazu ziemnego, a liczne szlaki handlowe przebiegające przez ten obszar. Według obliczeń Konferencji Narodów Zjednoczonych ds. Handlu i Rozwoju 70\% łącznej wartości światowego handlu realizowana jest drogami morskimi, w tym jedna trzecia tego przewozu odbywa się na szlaku handlowym przepływającym przez Morze Południowochińskie (UNCTAD, 2016). W związku z tym utrzymanie bezpieczeństwa na wodach tego akwenu jest jednym z najważniejszych punktów chińskiej polityki zagranicznej. Teza ta zresztą odnosi się również do rządów Tajwanu, Japonii i Południowej Korei (China Power, 2017). Wszystkie bowiem państwa realizujące import i eksport na Morzu Południowochińskim korzystają ze szlaków handlowych przebiegających przez Cieśninę Malakka, której blokada spowodowałaby katastrofalne skutki dla handlu światowego, i, co ma większe znaczenie z punktu widzenia przedmiotu analizy niniejszej pracy, dla chińskiej gospodarki. 
Wracając do analizy chińskich interesów geopolitycznych należy nadmienić, że ponad $60 \%$ chińskiego importu oraz eksportu realizowane jest drogami morskimi, z tego ponad 64\% tychże dróg morskich przebiega przez Morze Południowochińskie. Wodami tego morza Chiny eksportują towar wart około 900 miliardów dolarów rocznie. Dla porównania, drugim co do wielkości eksporterem jest Korea Południowa, a łączna wartość jej eksportu to tylko 249 miliardów dolarów. Singapur zaś zajmuje miejsce trzecie w omawianym zestawieniu, z wartością eksportu równą tylko 214 miliardów dolarów. O potędze chińskiego eksportu realizowanego szlakami morskimi wytyczonymi przez Morze Południowochińskie świadczyć może fakt, że dopiero po zsumowaniu wartości eksportu wszystkich pięciu pozostałych państw korzystających z tychże szlaków, uzyskamy wartość równą tej wyznaczonej przez chiński eksport (China Power, 2017).

\section{Wykres 3. Lączna wartość eksportu na Morzu Południowochińskim}

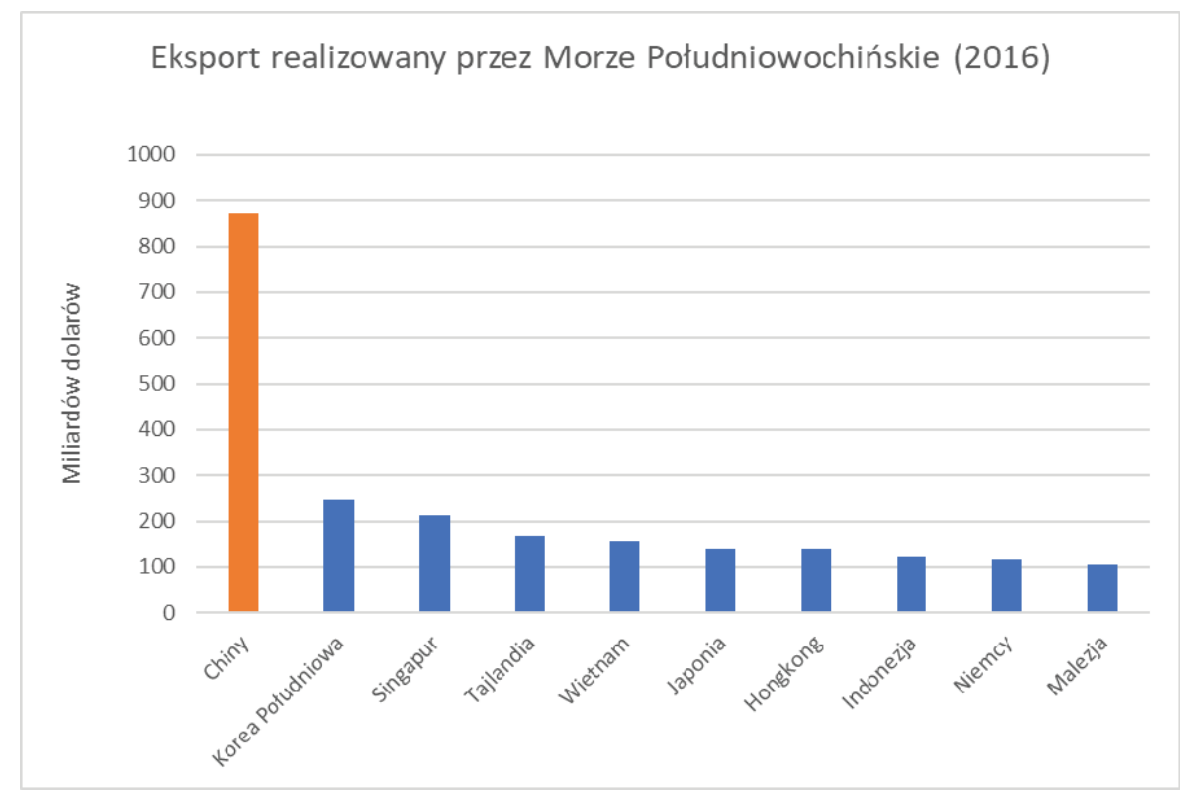

Źródło: China Power, 2017. 
Chociaż skala piractwa na Morzu Południowochińskim nieustannie maleje, to jeszcze na końcu XX w. rządy wszystkich państw nadbrzeżnych borykały się z problemem łupienia i porywania statków przewożących eksportowany towar. Jeszcze w 2004 r. działalność piracka na Morzu Południowochińskim stanowiła około 40\% łącznej światowej działalności piractwa (Montakle, 2016). Chociaż dzięki współpracy sił Indonezji, Malezji i Singapuru z roku na rok skala działalności przestępczej w rejonie tego akwenu stopniowo maleje, to skala zjawiska zaobserwowana na przełomie XX i XXI w. zachęca autora niniejszej pracy do sformułowania tezy, jakoby dzisiejsze Chiny nie mogły pozwolić na anarchię na Morzu Południowochińskim. Gospodarka chińska, chociaż ciągle w fazie zaskakującego rozwoju, jest bowiem gospodarką powoli zwalniającą oraz coraz bardziej podatną na różnego rodzaju zaburzenia, jak chociażby zakłócenia w działaniu jej głównej arterii handlowej, tj. szlaków handlowych przebiegających najpierw przez Morze Południowochińskie, a następnie przez Cieśninę Malakka.

Cieśnina ta jest zresztą najszybszym i najtańszym sposobem na wypłynięcie z Morza Południowochińskiego, stąd nie dziwi fakt, że prowadzi przez nią większość szlaków handlowych. Uzależnienie jednak gwarancji obrotu oraz możliwości prowadzenia handlu z zamorskimi partnerami handlowymi od dostępności cieśniny położonej, z uwagi na państwa nadbrzeżne oraz do niedawna wysoki poziom piractwa, w rejonie określonym raczej jako niebezpieczny, nie umknęło uwadze akademików oraz polityków Chińskiej Republiki Ludowej. W rzeczy samej już w 2003 r. prezydent Hu Jintao alarmował o wspomnianym niebezpieczeństwie, na co zresztą szybko zwróciły uwagę chińskie media, a potrzeba znalezienia innych rozwiązań przy wytaczaniu szlaków transportowych uzyskała medialne miano „Dylematu Cieśniny Malakka” (Pengzhi, 2014).

Próby wytyczenia alternatywnych szlaków handlowych czy to przez Cieśninę Sundajską, czy to przez Cieśninę Lombok nie tylko nie rozwiązałaby problemu koncentracji ścieżek handlowych w małym punkcie o wątpliwej stabilności geopolitycznej, ale również znacząco zwiększyłyby koszty transportu. Jedyną trasą transportową wolną od wspomnianej wady, to jest ryzyka zatorowości, byłaby trasa opływająca Australię, która jednak z oczywistych względów stanowiłaby trasę absurdalnie kosztowną. 
Mapa 1. Potencjalne szlaki handlowe na Morzu Południowochińskim

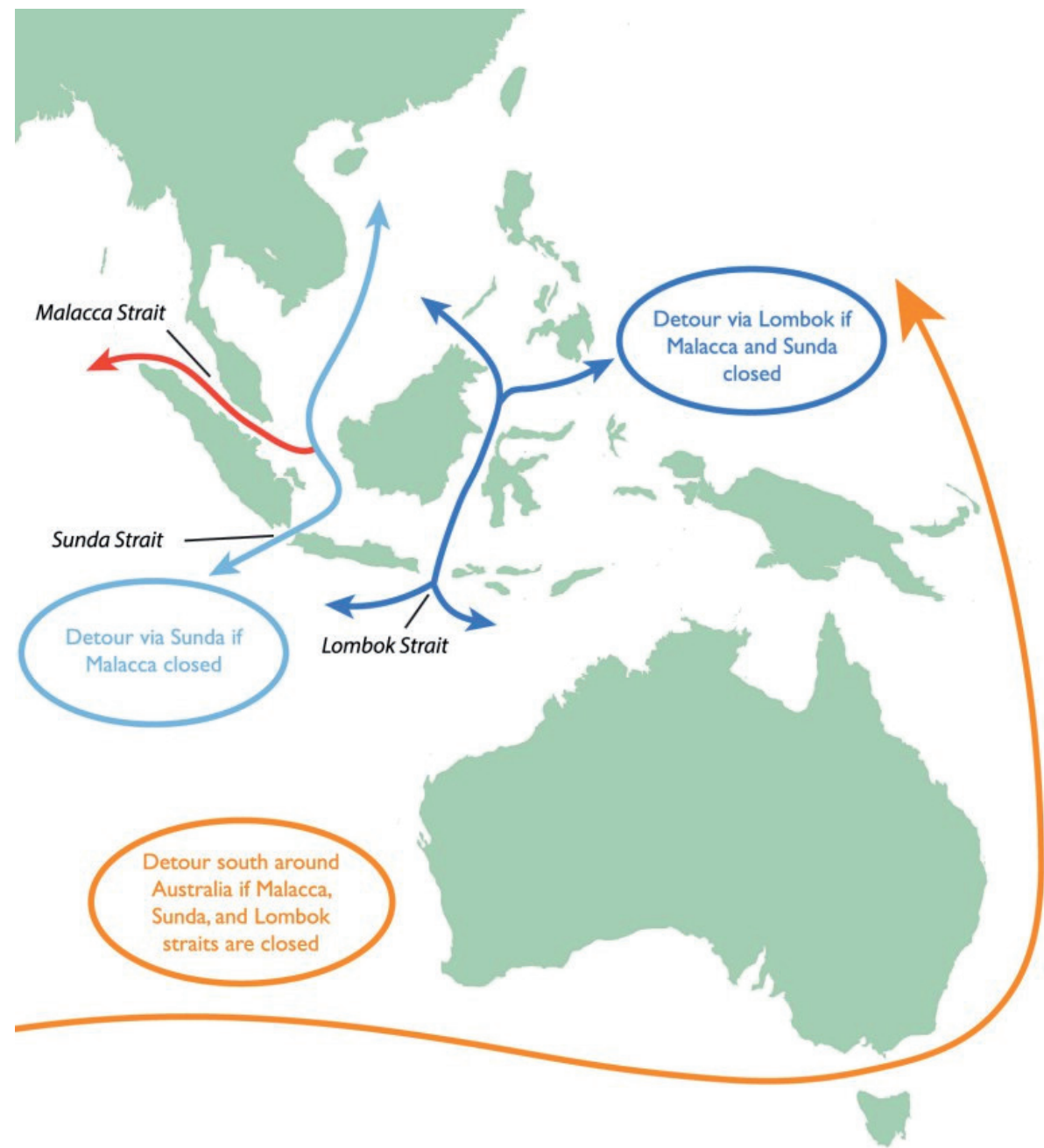

CSIS | ⿷RChina Power Project

Zgodnie z obliczeniami zaproponowanymi przez ośrodek analityczny China Power, tygodniowe zamknięcie Cieśniny Malakka i przekierowanie statków na inne szlaki spowodowałoby straty w wysokości około 64,5 milionów dolarów (tygodniowo). Gdyby żadna z pozostałych cieśnin nie była dostępna, co jest prawdopodobne na przykład w wypadku konfliktu zbroj- 
nego na Morzu Południowochińskim, korzystanie z trasy opływającej Australię przyniosłoby stratę w wysokości 2,8 miliarda dolarów miesięcznie. O ile w perspektywie tygodnia taka strata byłaby po prostu dość dużym ciosem w przedsiębiorstwa chińskie, w skali kilku miesięcy możemy mówić o poważnej przeszkodzie, zakłócającej prawidłowe działanie gospodarki. Jeżeli jeszcze raz przywołamy fakt, że ponad $60 \%$ chińskiego handlu realizowana jest drogą morską, dojdziemy do wniosku, że każde większe zakłócenie dostępności Morza Południowochińskiego byłoby katastrofalne dla chińskiej gospodarki, opartej w dużej mierze na eksporcie dóbr (China Power, 2017).

\section{Wprowadzenie do sytuacji politycznej i prawnej}

Skoro teza jakoby Morze Południowochińskie było krytyczne dla chińskich interesów gospodarczych została już dogłębnie uargumentowana, należałoby przejść do analizy konkretnych problemów prawnych oraz politycznych występujących na tymże morzu, w tym sprawdzić czy teza jakoby chińska obecność na Morzu Południowochińskim stopniowo się zwiększała jest twierdzeniem prawdziwym.

Początki sporów terytorialnych wyznacza traktat pokojowy podpisany w San Francisco w 1951 r. Na mocy tego traktatu Japonia została zobligowana do zwrotu Wysp Spratly (南沙群岛) i innych terenów zajętych na Morzu Południowochińskim, jednak sam traktat nie określał komu miałyby przysługiwać do nich suwerenne prawa (Fabrizzi, 2017). To „jednostronne” pozbawienie własności, bez wskazania sukcesora pokonanej Japonii, zostało wyrażone już w deklaracji poczdamskiej w 1945 r. Republika Chińska, niejako korzystając z sytuacji w której stan prawny omawianego terytorium nie był należycie uregulowany, w 1946 r. objęła część wysp w posiadanie za pomocą marynarki (Chen, 1979), a co do reszty nieposiadanego terytorium, wysunęła roszczenia, których zakres ujęty został za pomocą „linii jedenastu punktów”. Linia ta, zaprezentowana w 1947 r., a bazująca na dokumentach sporządzonych przez Komitet Inspekcji Lądowej i Morskiej Republiki Chińskiej w 1935 r., została przejęta przez rząd Chińskiej Republiki Ludowej w 1949 r., kiedy to objął on panowanie nad Chinami kontynentalnymi. Przebieg tejże linii zmieniał się z biegiem czasu, zresztą sama linia nigdy nie 
wyznaczała skonkretyzowanych granic roszczeń, a służyła tylko jako przybliżone wyznaczenie terytorium, wobec którego rząd chiński rościł sobie prawa. Dzisiejszy przebieg linii wyznaczony jest przez treść Notes Verbales opublikowanych w 2009 r. (Bureau of Oceans and International Enviroment, 2014) oraz mapę opublikowaną przez Hunan w 2014 r. (Thi Lan Anh, 2014). Posługując się pewnym uogólnieniem można stwierdzić, że terytorium wobec którego zgłaszane są roszczenia obejmuje około 2 miliony metrów kwadratowych przestrzeni morskiej i 13 kilometrów kwadratowych powierzchni morskiej, tj. wszystkie masy lądowe unoszące się nad powierzchnią morza, w tym m.in.: Wyspy Paracelskie (西沙群岛), wyspy Spratly (南沙群岛) oraz rafę Scarborough (黄岩岛). Dwa przywołane łańcuchy wysp oraz rafa Scarborough są jedynymi z nielicznych elementów nadających się do zabudowy na Morzu Południowochińskim. Posiadanie niniejszych jest więc jedynym sposobem na budowę jakiejkolwiek infrastruktury umożliwiającej sprawowanie kontroli nad przedmiotowym morzem (Bureau of Oceans and International Enviroment, 2014).

Jednak Morze Południowochińskie to od stuleci nie tylko akwen kluczowy dla Chin, ale również i innych państw nadbrzeżnych, czyli Wietnamu, Malezji, Brunei i Filipin. Kraje te, dla których rybołówstwo oraz inne sposoby eksploatacji morza są filarem gospodarek, już po zakończeniu II wojny światowej zgłosiły roszczenia do przysługujących im suwerennych praw wobec przedmiotowego akwenu. Natomiast co do wielkości tych roszczeń należy na wstępie zauważyć, że strefy wobec których miałyby krajom nadbrzeżnym przysługiwać suwerenne prawa kolidują ze sobą w znaczący sposób, szczególnie w rejonie wysp Spratly (Cobus, 2016). Nie jest więc tak, że konflikt na Morzu Południowochińskim jest konfliktem między Chinami a pozostałymi państwami nadbrzeżnymi. Jest to bowiem konflikt między pięcioma różnymi państwami, z których każde próbuje zaspokoić swoje interesy w sposób najpełniejszy, co oczywiście nie może nie pociągnąć strat $\mathrm{w}$ interesach pozostałych rywali.

Wietnam, będący w posiadaniu jedynie południowo-zachodniej części łańcucha wysp Spratly, bazując na argumentach historycznych i ekonomicznych rości sobie prawa do całego łańcucha wysp Paracelskich i części łańcucha wysp Spratly Filipiny, które władztwo sprawują wyłącznie nad kilkoma rafami i wyspami w łańcuchy Wysp Paracelskich, w kręgu swoich zainteresowań umieściły cały tenże łańcuch oraz wyłączne prawa do 
rafy Scarborough. Malezja, kontrolująca zaledwie trzy unoszące się ponad powierzchnią morza masy lądowe, swoje roszczenie wyznaczyła poprzez ustanowienie specjalnej strefy, rozciągającej się od jej linii brzegowej, do południowej części Wysp Paracelskich włącznie. Brunei, która w swoim posiadaniu nie ma ani jednej wyspy czy też rafy, przez to zwana „cichym żądającym”, swoje roszczenia ograniczyła do prostokątnego wycinka Morza Południowochińskiego rozciągającego się od linii podstawowej (brzegowej) do południowej części wysp Spratly. Wreszcie Tajwan, którego żądania pozostają w zgodzie z żądaniami chińskimi, a wyznaczone są przez linię dziewięciu punktów, która zresztą pokrywa się z linią prezentowaną przez rząd ChRL (Cobus, 2016). Wszystkie z wymienionych państw używają szeregu różnorodnych argumentów o różnej efektywności, od historycznych i gospodarczych zaczynając na prawnych kończąc. Wszystkie te państwa również nie stronią od działań faktycznych, często o dosyć agresywnym charakterze, które to działania niejednokrotnie doprowadzały do incydentów politycznych, a nawet potyczek zbrojnych. Do grupy państw zaangażowanych w konflikt należałoby również pośrednio zakwalifikować Tajlandię czy Kambodżę. Kraje te bowiem nie wysuwają bezpośrednio roszczeń terytorialnych, jednak z uwagi na połączenie Zatoki Tajlandzkiej z Morzem Południowochińskim czują się zobowiązane do nawoływania do polubownego rozstrzygnięcia sporu, co zresztą motywowane jest faktem, że w najlepszym interesie leży utrzymanie pokoju na Morzu Południowochińskim (Esguerra, 2017). 
Mapa 2. Porównanie roszczeń wysuwanych przez państwa nadbrzeżne Morza Południowochińskiego

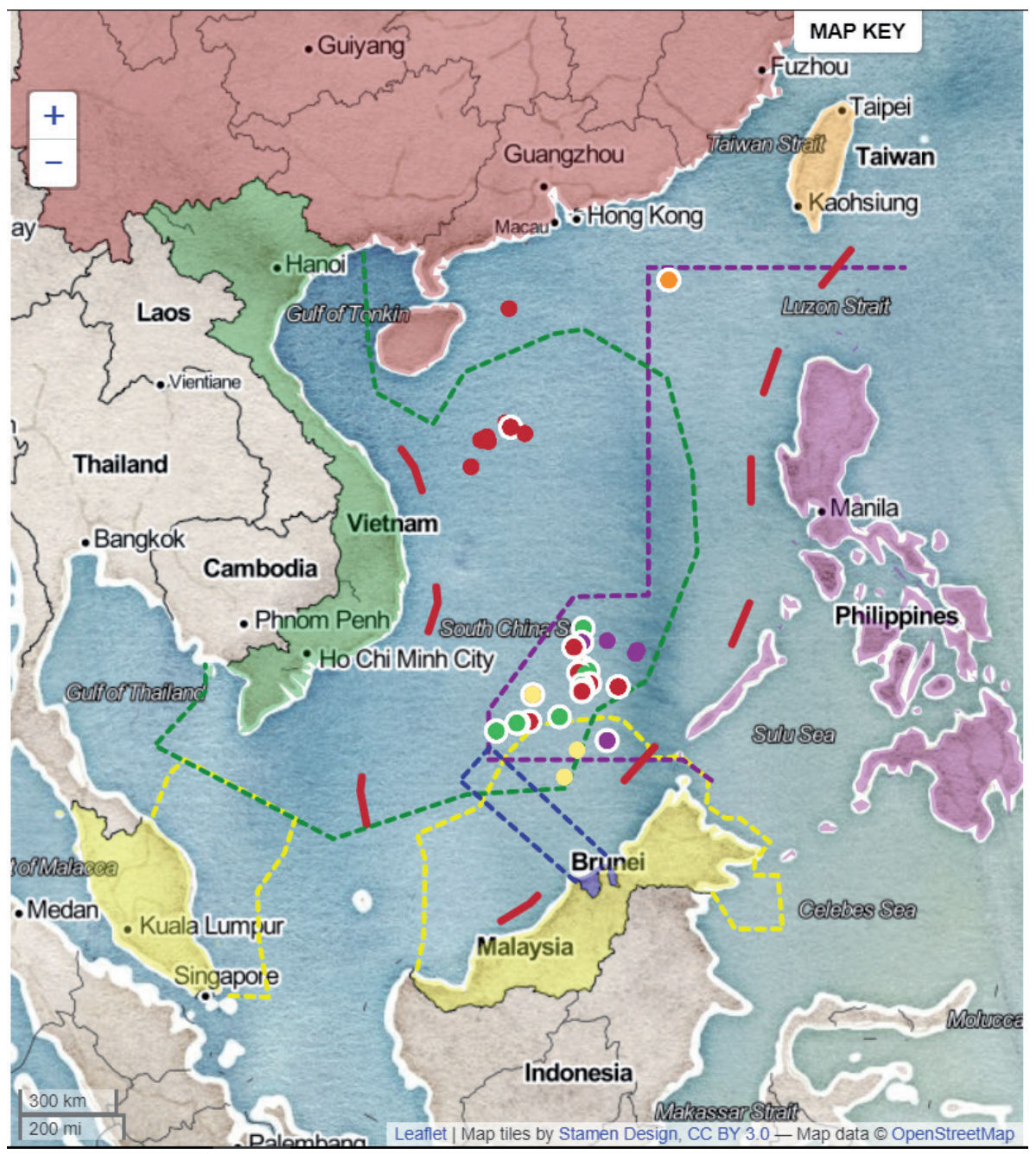

Źródło: Cobus, 2016.

\section{Aspekty prawne konfliktu}

Podstawowym dokumentem prawnym regulującym prawo korzystania z morza i jego zasobów naturalnych jest Konwencja Narodów Zjednoczo- 
nych o prawie morza z Montago Bay, podpisana 10 grudnia 1982 r. Jest ona zwieńczeniem trwającej dziewięć lat III Konferencji Prawa Morza, która „uznawana jest powszechnie za jedną z największych i najważniejszych konferencji w historii stosunków międzynarodowych", a dokument wypracowany w jej toku jest „swojego rodzaju konstytucją mórz i oceanów regulującą sposoby ich użytkowania, badania i ochrony" (Bierzanek, Symonides, 2004). Aktualnie 168 państw jest uczestnikami konwencji (UNCLOS, 2018), a o jej znaczeniu świadczyć ma również fakt, że nawet państwa które nie ratyfikowały Konwencji powołują się na jej postanowienia, mające w myśl tych powoływań rangę międzynarodowego prawa zwyczajowego.

Nie może więc dziwić fakt, że wszystkie z państw uczestniczących $\mathrm{w}$ analizowanym sporze powołują się właśnie na postanowienia tejże Konwencji. Operują one dwoma podstawowymi pojęciami skonstruowanymi przez nią; instrumentem prawnym zwanym wyłączną strefą ekonomiczną oraz instrumentem prawnym szelfu kontynentalnego. Wyłączna strefa ekonomiczna jest obszarem o szerokości 200 mil morskich od linii podstawowej ${ }^{1}$. Obszar ten nie stanowi już formalnie terytorium państwa, ale wyznacza maksymalny zasięg suwerennych praw ekonomicznych państwa nadbrzeżnego (Bierzanek, Symonides, 2004), czyli określa na jakim terenie państwu przysługuje prawo do pobierania pożytków i eksploatacji morza. Drugim przywołanym instrumentem jest szelf kontynentalny, który stanowi naturalne przedłużenie kontynentu, zaś państwo ma prawo do jego eksploatacji do 350 mil morskich (Barcik, Srogosz, 2007). Po przekroczeniu tej granicy, nawet jeśli szelf ciągnie się dalej, państwu nadbrzeżnemu nie wolno już prowadzić odwiertów czy w inny sposób używać dna morskiego dla celów własnych. Obie te regulacje prawne zostały skonfrontowane ze stanem faktycznym zastanym na Morzu Południowochińskim przez Stały Trybunał Arbitrażowy w Hadze, na wniosek Filipin złożony 22 stycznia 2013 r. pod rządami Benigno Aquino (BBC, 2010). Korzystając z procedury przewidzianej w Aneksie VII Konwencji Narodów Zjednoczonych o prawie morza Filipiny wystąpiły do Stałego Trybunału Arbitrażowego w Hadze w sprawie rozstrzygnięcia sporu powstałego między Filipinami a Chińską Republiką Ludową, w tym o rozstrzygnięcie

1 Linia ta, nie wchodząc w zbędne szczegóły, tworzona jest przez połączenie najbardziej wysuniętych punktów lądu. 
zasadności chińskich roszczeń opartych na argumentach historycznych (linii dziewięciu punktów) czy o zweryfikowane legalności różnego rodzaju działań faktycznych podejmowanych przez rząd chiński (PCoA, 2016). Była to odpowiedź Filipin na przejęcie przez ChRL rafy w odległości około 140 mil od wybrzeża Filipin (Perlez, 2016). Chiny zdecydowanie odmówiły udziału w arbitrażu (Hao, 2013), powołując się przy tym na postanowienia dwustronnej konwencji zawartej pomiędzy ASEAN a ChRL, z której wynika, że wszelkie spory dotyczące Morza Południowochińskiego rozstrzygane mają być $\mathrm{w}$ drodze dwustronnych negocjacji i w sposób koncyliacyjny (ASEAN, 2012). Chiny tym samym zrezygnowały z możliwości wyboru sędziego do składu orzekającego ${ }^{2}$. Co do obecności osób trzecich $\mathrm{w}$ przedmiotowym procesie, Tajwan nie został zaproszony do uczestnictwa, zaś Wietnam formalnie złożył deklarację poparcia dla filipińskiej petycji oraz podniósł również zarzut bezprawności linii dziewięciu punktów (Boudreau, 2014). W czerwcu 2016 r. Trybunał rozstrzygnął na korzyść Filipin siedem z piętnastu postawionych Chinom zarzutów. Rozstrzygnięcie pozostałych siedmiu uznał za nieleżące w jego kompetencji, natomiast jeden z postawionych zarzutów określił jako wymagający doprecyzowania. Podzielił on w pełni twierdzenia wysuwane przez stronę chińską jakoby nie był on właściwy do rozstrzygania sporów o przysługującą stronom konwencji suwerenność wobec poszczególnych elementów morskich oraz nie miał upoważnienia do wytyczania jakichkolwiek granic czy to granic państwowych, czy też granic morza terytorialnego lub wyłącznej strefy ekonomicznej. Rozstrzygnął on jednak, że linia dziewięciu punktów znacząco przekracza dopuszczalną maksymalną szerokość wcześniej przywołanych stref, w rejonie których państwu nadbrzeżnemu przysługują prawa do eksploatacji morza. Stwierdził on również, że Konwencja Narodów Zjednoczonych o prawie morza nie umożliwia uzyskania wyłącznych praw do jakiegoś obszaru w oparciu o racje historyczne. Trybunał zaklasyfikował również akcje organizowane przez rząd Chin, a mające na celu odcięcie filipińskich rybaków od wód w rejonie rafy Scarborough jako bezprawne w rozumieniu Konwencji Narodów Zjednoczonych o prawie morza (Fabrizi, 2017). Chiński rząd, który od początku niechętny był procedurze prowadzonej przez Trybunał, co oczywiste, odrzucił wyrok jako

\footnotetext{
${ }^{2}$ Możliwość taka przysługiwała ChRL na mocy art. 3 Aneksu VII konwencji.
} 
„kierowany motywami politycznymi”. Podniósł on zarzut ingerencji w suwerenne prawa państw-sygnatariuszy Konwencji w sposób pośredni oraz zignorowanie postanowień traktatu zawartego pomiędzy Chinami a ASEAN, którego celem było poddanie przyszłych sporów wynikłych z użytkowania Morza Południowochińskiego pod rozstrzygnięcie koncyliacyjne.

Wydawałoby się, że chociaż wyrok nie będzie respektowany przez rząd Chińskiej Republiki Ludowej to jednak Filipiny będą wywierać nacisk na opinię międzynarodową, aby przekonała Chiny do uznania wyroku oraz wykonania chociaż części jego postanowień. Nic takiego jednak nigdy nie miało miejsca, a same Filipiny szybko zrezygnowały z używania postanowień wyroku jako argumentów w sporze o Morze Południowochińskie (Fabrizi, 2017). Zbiegło się to w czasie $\mathrm{z}$ wyborem Rodrigo Roa Duterte na Prezydenta Filipin 28 maja 2016 r. (Cruz, 2016), który zrewidował politykę zagraniczną Filipin, kładąc większy nacisk na sojusznicze stosunki z Chinami, a lekko dystansując się od zachodnich partnerów Filipin (Fabrizi, 2017). Obserwując ostatnie wydarzenia (Liangyu, 2018) można dojść do wniosku, że prezydent Rodrigo Duterte spór o strefy kontroli na Morzu Południowochińskim będzie starał się rozstrzygnąć przez dwustronną współpracę, opartą w szczególności na inicjatywie „jednego pasa i jednego szlaku” (一带一路) oraz inicjatywie Jedwabnego Morskiego Szlaku XXI w. (21 纪海上丝绸之 路). Wydaje się również, że sama opinia publiczna Filipin nie jest chętna do zaostrzenia retoryki w stosunku do Chin, co wynika bezpośrednio z przeszłości tego kraju (Woods, 2016). Nie wnikając tutaj w historię Filipin, należy nadmienić że Filipińczycy traktują Chiny w sposób bardziej otwarty i partnerski, zaś z dużo większą rezerwą prowadzą politykę zagraniczną ze Stanami Zjednoczonymi Ameryki oraz innymi państwami Zachodu, które kojarzą im się z kolonialną przeszłością (Woods, 2016).

Skoro zaś wykonaniem wyroku nie jest zainteresowana żadna ze stron sporu, a w szczególności nie jest nim zainteresowany sam petent (co w sporach prawnych nie zdarza się dość często), to zdaje się że brak jest środków, którymi mogłoby operować prawo międzynarodowe aby rozstrzygnąć przedmiotowy spór. Mając na uwadze, że Konwencja Narodów Zjednoczonych o prawie morza jest powszechnie uważana za jedną z najbardziej kompletnych i najlepiej przyjętych umów międzynarodowych, trudno wyobrazić sobie skuteczniejszy środek prawny do rozstrzygnięcia waśni na Morzu Południowochińskim. Warto jednak znać stan prawny na tym- 
że morzu, w myśl uregulowań publiczno-międzynarodowych, ponieważ może okazać się, że regulacje te posłużą jeszcze państwom nadbrzeżnym do uregulowania stosunków, już nie w formie arbitrażu, ale być może $\mathrm{w}$ formie wielostronnych porozumień podmiotów zainteresowanych. Znajomość treści oraz podstaw prawnych wyroku konieczna jest również do zrozumienia argumentów przytaczanych przez rząd Stanów Zjednoczonych Ameryki odnośnie do analizowanego sporu.

\section{Działania ChRL na Morzu Południowochińskim}

Polityka Chińskiej Republiki Ludowej w stosunku do Morza Południowochińskiego uległa znacznemu przeobrażeniu w przeciągu ostatnich trzydziestu lat. Charakteryzując te zmiany można zaryzykować stwierdzenie, że stała się ona znacznie bardziej asertywna i pragmatyczna, jednak z roku na rok jest coraz mniej agresywna. Z całą pewnością w ostatnich latach nie dochodzi już do zbrojnych potyczek między flotami państw nadbrzeżnych, tak jak miało to miejsce w styczniu 1996 r., kiedy to chińskie jednostki marynarki uczestniczyły w dziewięćdziesięciominutowej wymianie ognia z jednostkami filipińskimi czy też w latach 80., kiedy to doszło do kilku zbrojnych starć między flotą Chin a flotą Wietnamu, które skończyły się śmiercią kilkudziesięciu osób (Rowan, 2005). Powodów tonowania retoryki w stosunku do sporów na Morzu Południowochińskim jest co najmniej kilka. Po pierwsze, Chiny stają się państwem coraz bardziej świadomym swojej własnej potęgi. Chociaż wzrost ekonomiczny Chin stopniowo zwalnia, a na horyzoncie wewnętrznej polityki ekonomicznej pojawiają się problemy trapiące rozwinięte państwa zachodnie (jak chociażby kryzys mieszkaniowy w dużych miastach), to ciągły rozwój gospodarczy Państwa Środka, który znacznie przekracza możliwości innych krajów azjatyckich, jest niezaprzeczalnym faktem (Bloomberg, 2018). Chiny, które dysponują dzisiaj znacznie większym kapitałem finansowym, jak i politycznym, a przede wszystkim, które są tego kapitału znacznie bardziej świadome, mogą sobie pozwolić na stopniowe stonowanie polityki wobec ich mniejszych sąsiadów, których możliwości militarne i polityczne są znacznie bardziej ograniczone. Same decyzje podejmowane wobec Morza Południowochińskiego były zresztą nie tylko kierowane motywami zewnętrznymi, 
ale również oddziaływać miały wewnętrznie na nastroje społeczeństwa chińskiego. W rzeczy samej rząd w Pekinie martwił się, że poczynienie licznych ustępstw podczas podejmowania decyzji politycznych odebrane będzie jako oznaka słabości przez społeczeństwo chińskie, co w dłuższej perspektywie doprowadzi do pojawienia się niepokojów społecznych i destabilizacji sytuacji politycznej (Jihyun, 2015). Zważając jednak na ostatnie wydarzenia, w szczególności na konsolidację władzy przez Xi Jinpinga (Rizzi, 2018) oraz jego szerokie poparcie społeczne, nie ma już potrzeby aby Pekin podejmując decyzje polityczne tak bardzo zważał na politykę wewnętrzną i nastroje społeczne.

Stopniowego tonowania polityki wraz $\mathrm{z}$ powstrzymywaniem się od agresywniejszych działań nie należy jednak mylić z porzuceniem swoich roszczeń. W 2010 r. Pekin w oficjalnym oświadczeniu uznał, że Morze Południowochińskie jest jedną z jego „kluczowych sfer zainteresowania”, co zresztą do dzisiaj nie uległo zmianie. 2016 r. był okresem wzmożonej aktywności chińskiej na tymże morzu, która skutkowała zbudowaniem ponad trzynastu tysięcy metrów kwadratowych sztucznego lądu, w większości na rafach posiadanych przez ChRL w obrzeżach łańcuchu Wysp Spratly ${ }^{3}$. Te sztuczne wyspy posłużyły jako fundamenty dla licznych instalacji wojskowych, w tym baterii przeciwlotniczych czy pasów startowych (najdłuższy z nich ma ponad trzy kilometry długości i umożliwia start dużego samolotu pasażerskiego) (Jihyun, 2018). Zaś same działania konstrukcyjne połączone zostały ze wzmożoną aktywnością Marynarki Wojennej ChRL (Westcott, Cohen, 2018).

Znaczną zmianą jednak jest fakt połączenia tej agresywnej polityki z działaniami o charakterze mniej drastycznym, a nawet licznymi próbami koncyliacyjnymi. Dobrym przykładem decyzji, która była dosyć zaskakująca dla postronnych obserwatorów było wycofanie platformy wiertniczej HYSY 981, umieszczonej w rejonie który uchodził za strefę wpływów Wietnamu. Oczywiście, zgodnie z azjatycką kulturą „zachowania twarzy”, oficjalnym powodem tego wycofania miało być zakończenie zaplanowanych operacji wiertniczych. Wycofanie platformy wiertniczej zaledwie po

${ }^{3}$ Należy nadmienić, że Chiny nie posiadają w tym łańcuchu zbyt wiele naturalnego lądu. 
roku prac nie jest jednak ruchem, na którego wykonanie zdecydowałby się Pekin jeszcze dwadzieścia lat temu (Jihyun, 2015).

\section{ASEAN, czyli działania podejmowane przez inne państwa nadbrzeżne na Morzu Południowochińskim}

W sierpniu 1967 r. ministrowie spraw zagranicznych Indonezji, Malezji, Filipin, Tajlandii i Singapuru podpisali deklarację, na mocy której do życia zostało powołane Stowarzyszenie Narodów Azji Południowo-Wschodniej (ASEAN) z siedzibą w Brunei. Celem statutowym tej nowo powołanej organizacji było inicjowanie współpracy o charakterze ekonomicznym, socjalnym, kulturalnym, technicznym i edukacyjnym, promowanie pokojowych metod rozwiązywania sporów oraz dbanie o stabilność i dobrobyt rejonu. Przez następne lata do zrzeszenia dołączyły państwa, takie jak m.in.: Brunei, Wietnam czy Kambodża (Rowan, 2015). Chociaż organizacja ta okazała się niezaprzeczalnie efektywna w koordynowaniu współpracy o charakterze ekonomicznym czy społecznym, to nie jest jednak zdolna stworzyć wspólnego frontu rywalizacji przeciw Chinom o Morze Południowochińskie. W znacznej części powodem tego jest fakt, że tak jak już wcześniej zostało przywołane, konflikt ten nie jest rywalizacją między Chinami a pozostałymi państwami Azji Południowej, lecz jest pokłosiem rywalizacji na zasadach bliższych „wszyscy ze wszystkimi o wszystko". Dlatego też nierealistyczne wydaje się, aby wymagać od organizacji, która zrzesza szereg państw o różnych interesach, sformułowania jednoznacznej linii argumentacyjnej, która byłaby jakąś przeciwwagą dla argumentów wysuwanych przez Pekin. Niewątpliwym sukcesem omawianego zrzeszenia było sformułowanie w 2002 r. już wcześniej przywołanej „Declaration on the Conduct of Parties in the South China Sea” (określanej w literaturze jako DOC). Deklaracji tej jednak nie można traktować jako wynik ugody dwóch zwaśnionych stron, lecz bardziej jako dokument o symbolicznym znaczeniu, pełny retorycznych wstawek, nieustanawiający zaś żadnych możliwych do wyegzekwowania norm prawnych. Dlatego też wątpliwa wydaje się teza wysuwana przez akademików na przełomie 
XX/XXI w. ${ }^{4}$, jakoby przeciwwagą dla ChRL miało stać się wspomniane stowarzyszenie, wspierane przez Stany Zjednoczone Ameryki i Japonię.

\section{Polityka USA wobec Morza Południowochińskiego}

Polityka Stanów Zjednoczonych Ameryki w stosunku do Morza Południowochińskiego jest zupełnie inna od tej prognozowanej na końcu XX w. USA, które pozostawały dotychczas bezczynne, dopiero za rządów prezydenta Baracka Obamy przesunęły środek ciężkości swojego geopolitycznego zainteresowania z Bliskiego Wschodu na rejony Azji formułując doktrynę znaną pod nazwą „Asian Pivot”. Realizacja tejże doktryny na Morzu Południowochińskim miała się odbywać poprzez wdrożenie programu „Freedom of Navigation”, który (według oficjalnych zapowiedzi) miał być nie tylko przeciwwagą dla rosnącej siły militarnej Chin, ale również zabezpieczać akweny łączące Pacyfik z krajami azjatyckimi, tym samym gwarantując wspominaną „wolność nawigacji”. W rzeczywistości jednak za rządów prezydenta Obamy marynarka Stanów Zjednoczonych oddelegowała na Morze Południowochińskie jeden niszczyciel rakietowy, który nie był w stanie wywrzeć skutecznej presji na żaden z państw nadbrzeżnych (Fabrizi, 2017). Administracja Donalda Trumpa bardziej zaś zainteresowana jest działaniami o charakterze ekonomicznym, niż faktycznym zwiększaniem obecności Ameryki na Morzu Południowochińskim. Oprócz incydentalnych zaczepek (Browne, 2018), które są bardziej objawem słabnącego wpływu USA na sytuację polityczną Azji niż przejawem skoordynowanego działania, obecność Ameryki w tej części świata staje się mało zauważalna. Prowadzi to do dość ciekawej sytuacji, w której Chińczycy nie tyle uzyskują faktyczne panowanie nad Morzem Południowochińskim, ile uzyskują coś, co w zagranicznej literaturze określane jest mianem soft power, czyli pośrednie instrumenty zaspokajania swoich interesów, bez potrzeby uciekania się do środków przymusu.

\footnotetext{
4 Por. The US-Japan Security Alliance, ASEAN, and the South China Sea Dispute.
} 


\section{Czy Chiny chcą mieć morze na wyłączność? Prognozowanie oraz tezy z piśmiennictwa}

Przechodząc do konkluzji pracy chciałbym wskazać na prawdopodobne scenariusze, możliwości rozwoju sytuacji na Morzu Południowochińskim. Jest to jednak o tyle trudne, że o ile udowodnienie tez o wartości strategicznej tego morza czy o niemożności zastosowania aktualnego prawa międzynarodowego do rozstrzygnięcia sporów na tymże morzu opiera się zawsze w większej lub mniejszej mierze na faktach, analizach oraz na innych danych, których prawdziwość łatwo zweryfikować, formułowanie osądów o charakterze prognostycznym wiąże się zawsze $\mathrm{w}$ jakimś stopniu $\mathrm{z}$ niepewnością i zgadywaniem. Dlatego nie wydaje mi się wskazane, aby nakreślać tutaj jakieś dalekosiężne scenariusze rozwoju zdarzeń, a skupić się na tym, co bezpośrednio wynika z przytoczonych faktów. Prawdą bowiem jest, że obecność Chin na Morzu Południowochińskim w sposób nieprzerwany wzrasta czy to jeżeli chodzi o faktyczną ilość jednostek marynarki, czy to o wcześniej wspomniane możliwości działania w zakresie przywołanego soft power. Zmienia się jednak przy tym charakter działań podejmowanych przez Pekin. Coraz więcej z nich swoją genezę wywodzi z planu Nowego Jedwabnego Szlaku, jak chociażby potężne finansowanie infrastruktury morskiej w Kambodży (Kunmakara, 2018). Duża część z nich ma również charakter stabilizacyjny, z Chinami występującymi w roli głównego mediatora, tak jak zapowiedzi rozwoju wcześniej wspomnianej deklaracji (DOC) w ramach współpracy między ASEAN a ChRL (Pomfret, Morales, 2017). Wśród tez z piśmiennictwa najbardziej przekonująca jest ta prezentująca Chiny jako supermocarstwo, potrzebujące ustanowić własną strefę wpływów, w szczególności w rejonach w których w przeszłości posiadało taką strefę wpływów (Woods, 2016). Teza ta, jakkolwiek banalnie by nie brzmiała, zakłada jedną ważną implikację: własna strefa wpływów nie oznacza równocześnie absolutnej dominacji regionu za pomocą środków militarnych. Wręcz przeciwnie, Chiny pragną kształtować swoje najbliższe środowisko w sposób zgodny ze swoją wolą, jednak w jakiejś mierze również z wolą najbliższych sąsiadów. Teza ta dodatkowo wzmocniona jest ar- 
gumentami o wartości historycznej, w tym porównaniu aktualnych działań do tradycyjnej polityki Chin w stosunku do Morza Południowochińskiego praktykowanej przez ostatnie dwa tysiąclecia. Zgodnie ze słowami premiera Chin, które padły niespełna rok temu (Pomfret, Morales, 2017), Morze Południowochińskie to akwen o krytycznej wartości strategicznej dla Chin. Wartość ta manifestuje się jednak głównie w obecnej stabilności regionu, która pozwala na niezakłócony przepływ statków handlowych pływających pod chińską banderą, w korzystnych relacjach z państwami nadbrzeżnymi, które stanowią dla Chin ważne rynki zbytu swoich usług oraz w tworzeniu z tymi państwami sojuszy lokalnych mogących stanowić przeciwwagę dla polityki realizowanej przez głównego rywala Chin - Stany Zjednoczone Ameryki. Mając powyższe na uwadze, Pekin potrzebuje spokojnych wód na Morzu Południowochińskim, które pozwolą mu realizować dalej politykę dynamicznego rozwoju, a ceną jaką jest gotów zapłacić jest zapewne możliwość poczynienia ustępstw czy to $\mathrm{w}$ dzieleniu się zyskami z eksploatacji dóbr naturalnych tego morza, czy wycofania się ze znacznej części swoich roszczeń terytorialnych.

MACIEJ ZUZIAK

Wydział Prawa i Administracji

Uniwersytet Śląski

Międzywydziałowe Koło Kultury i Prawa Chińskiego

ul. Bankowa 11b, 40-007 Katowice

maciejzuziak101@gmail.com

\section{Bibliografia}

\section{Monografie}

Barcik, J., Srogosz, T. (2007). Prawo Międzynarodowe Publiczne. Warszawa: C.H. Beck. Bierzanek, R., Symonides, J. (2004). Prawo Międzynarodowe Publiczne. Warszawa: Wolters Kluwer.

Chen, K. (1987). China's War with Vietnam, 1979: Issues, Decisions, And Implications. Stanford, California: Hoover Institution Press. 


\section{Artykuły w czasopismach, drukach zwartych}

Jihyun, K. (2015). Territorial Disputes in the South China Sea Implications for Security in Asia and Beyond. Strategic Studies Quarterly, 9(2), 107-141.

Pengzhi, H. (2014). Analysis of Three Causes of the Malacca Dilemma. Theory Research, 33, 11-12.

Rowan, J. (May/June 2016). The U.S.-Japan Security Alliance, ASEAN, and the South China Sea Dispute. Asian Survey, 45(3), 414-436.

Woods, S. (June 2016). The Sino-Philippine South China Sea Dispute. American Journal of Chinese Studies, 23(1), 159-171.

\section{Artykuły w pracach zbiorowych}

Fabrizi, R. (2017). Strategic Control. W: J. Golley, L. Jaivin. L. Tomba (red.), Control (317-334). Canberra: ANU Press.

\section{Materiały ośrodków analitycznych}

Bureau of Oceans and International Enviromental and Scientific Affairs. (2014). Maritime Claims in the South China Sea. Pobrane z: https://www.state.gov/documents/organization/234936.pdf.

China Power. (2017). How much trade transits the South China Sea. Pobrane z: https:// chinapower.csis.org/much-trade-transits-south-china-sea/.

UNCTAD. (2016). Review of Maritime Transport. Pobrane z: http://unctad.org/en/ PublicationsLibrary/rmt2016_en.pdf.

United States Energy Information Administration. (2013). South China Sea Analysis. Pobrane z: https://www.eia.gov/beta/international/regions-topics.cfm?RegionTopicID=SCS.

\section{Netografia}

Case view (No. 2013-19). (2016). Permanent Court of Arbitration. Pobrane z: https:// www.pcacases.com/web/view/7.

Declaration on the Conduct of Parties in the South China Sea. (2012). Pobrane z: http:// asean.org/?static_post=declaration-on-the-conduct-of-parties-in-the-south-china-sea.

Nazewnictwo Geograficzne Świata, Morza i oceany. (2008). Komisja Standaryzacji nazw geograficznych poza granicami Rzeczypospolitej Polskiej przy Głównym Geodecie Kraju. Pobrane z: http://ksng.gugik.gov.pl/pliki/zeszyty/zeszyt_10.pdf.

\section{Publikacje elektroniczne}

Benigno Aquino sworn in as new Philippine president. (2010). BBC News. Pobrane z: http://www.bbc.com/news/10457448.

Boudreau, J. (2014). South China Sea Tensions Flare as Vietnam Files Stance to Court. Bloomberg. Pobrane z: https://web.archive.org/web/20141213103712/http:/mobile.bloomberg.com/news/2014-12-12/south-china-sea-tensions-flare-as-vietnam-files-stance-to-court.html. 
Browne, R. (2018). US flies bombers over South China Sea. CNN News. Pobrane z: https://edition.cnn.com/2018/04/27/politics/us-flies-bombers-south-china-sea/ index.html.

China's Economic Growth Remains Robust Amid Strong Retail Sales. (2018). Bloomberg News. Pobrane z: https://www.bloomberg.com/news/articles/2018-04-17/ china-economic-growth-remains-robust-amid-strong-retail-sales.

Chronological lists of ratifications of, accessions and successions to the Convention and the related Agreements. (2018). Oceans and Law of the Sea, United Nations. Pobrane z: http://www.un.org/Depts/los/reference_files/chronological_lists_of_ratifications.html.

Cobus, P. (2016). Conflict and Diplomacy on the High Seas. VOA News. Pobrane z: https://projects.voanews.com/south-china-sea/.

Cruz, R. (2016). It's Digong by landslide, Leni by hairline. ABS CBN News. Pobrane z: http://news.abs-cbn.com/halalan2016/nation/05/27/16/its-digong-by-landslide -leni-by-hairline/.

Esguerra, C. (2017). Thailand seeks full implementation of South China Sea declaration. ABS CBN News. Pobrane z: http://news.abs-cbn.com/news/04/28/17/thailand-seeks-full-implementation-of-south-china-sea-declaration.

Hao, Z. (2013). China rejects arbitration on disputed islands in S.China Sea. CCTV. Pobrane z: http://english.cntv.cn/program/newsupdate/20130719/104385.shtml.

Kunmakara, M. (2018). China-Cambodia venture to build new Kampot port. Khmer Times. Pobrane z: https://www.khmertimeskh.com/50483122/china-cambodiaventure-to-build-new-kampot-port/.

Liangyu. (2018). Xi calls for elevating Sino-Philippine ties. Xinhuanet News. Pobrane z: http://www.xinhuanet.com/english/2018-04/10/c_137101155.html.

Montlake, S. (2016). Hard times for pirates in busy world waterway. The Christian Science Monitor. Pobrane z https://www.csmonitor.com/2006/1030/p01s04-woap. html.

Perlez, J. (2016). Philippines v. China: Q. and A. on South China Sea Case. The New York Times. Pobrane z: https://www.nytimes.com/2016/07/11/world/asia/southchina-sea-philippines-hague.html.

Pomfret, J., Morales, N. (2017). South China Sea code of conduct talks to be 'stabilizer' for region: China premier. Reuters. Pobrane z: https://www.reuters.com/article/ us-asean-summit-southchinasea/south-china-sea-code-of-conduct-talks-to-bestabilizer-for-region-china-premier-idUSKBN1DE05K.

Rizzi, G. (2018). Xi Jinping: China's Emperor for life? Global Risk Insights. Pobrane z: https:/globalriskinsights.com/2018/03/xi-jinping-the-rise-of-chinas-emperor/.

Thi Lan Anh, N. (2014). New ten-dashed line map revealed China's ambition. Thanhnien News. Pobrane z: http://www.thanhniennews.com/commentaries/ new-tendashed-line-map-revealed-chinas-ambition-28816.html.

Westcott, B., Cohen, Z. (2018). US challenged by China's navy in South China Sea. CNN News. Pobrane z: https://edition.cnn.com/2018/03/28/asia/south-china-seadrills-liaoning-intl/index.html. 